\title{
Billionaires in Global Philanthropy: a Decade of the Giving Pledge
}

\author{
Hans Peter Schmitz ${ }^{1}$ Elena M. McCollim ${ }^{2}$ \\ Published online: 25 May 2021 \\ (C) Springer Science+Business Media, LLC, part of Springer Nature 2021
}

\begin{abstract}
Billionaire philanthropists claim to play a key role in advancing well-being and public goods across the world. One of the most prominent recent expressions of these efforts is the Giving Pledge, created in 2010 by Bill and Melinda Gates in collaboration with Warren Buffett. After a decade of its existence, this analysis of the Giving Pledge population and its commitment letters shows an overall dominance of white, male, and US-based billionaires among the signatories. Tech billionaires are a wealthier and younger subgroup of pledgers than their counterparts in other industries. The pledge letters reveal an emphasis on education and health as dominant philanthropic causes. Among explanations for giving, the four most frequent reasons mentioned are a desire to make a difference, a wish to give back, a sense of personal fulfillment resulting from giving, and references to being socialized into philanthropic giving early in life. While the Giving Pledge is the most prominent global effort to increase philanthropic giving among the wealthy, the voluntary nature and relatively modest commitment goal make it difficult to assess its significance and impact.
\end{abstract}

Keywords Billionaires $\cdot$ Philanthropy $\cdot$ Giving Pledge $\cdot$ Bill and Melinda Gates $\cdot$ High-net-worth individuals

\section{Introduction}

During the COVID-19 pandemic, the number of billionaires increased by 660 individuals to 2755 in only one year between March 2020 and March 2021 (Forbes 2021). This significant increase draws attention to the power of billionaires in shaping domestic and global public policies through their philanthropy (Callahan 2017; Giridharadas 2018), especially at a time when many citizens face profound economic and social uncertainty. Accelerated wealth accumulation has put a spotlight on billionaires and their often bold claims about addressing societal ills and solving long-standing global problems (Bishop \& Green 2008; Horvath \& Powell 2016). In the USA, this new wealth has been transformative as new philanthropic

Hans Peter Schmitz

schmitz@sandiego.edu

Elena M. McCollim

elena.mccollim@faculty.umgc.edu

1 University of San Diego, 5998 Alcala Park, San Diego, CA 92110, USA

2 University of Maryland Global Campus, 1616 McCormick Dr, Largo, MD 20774, USA institutions created after 1990 are responsible for half of foundation giving today (Ferris 2016, 322). Bill and Melinda Gates are today major actors in the global health field, rivaling the role of the World Health Organization (WHO) and other government-backed international institutions. The efforts of extremely wealthy individuals shaping public policies at global and national levels raise questions about the appropriate roles and accountability of private actors shaping how the less wealthy live (Skocpol 2016).

Billionaires have responded to criticisms of unequal wealth accumulation in a number of different ways. Some of the very wealthy respond to the increased attention by keeping a low profile, while others are prompted to spend their wealth to advance public goods, for example, by buying ailing newspapers (Kulish 2021) or engaging in generous philanthropic giving (Forbes Wealth Team 2021). While this generates substantial and often positive publicity, many billionaires continue to grow their wealth and directly contribute to rising economic inequality. For example, Warren Buffett has given away approximately US $\$ 37$ billion over the past decades, but his own wealth more than doubled in the past decade from roughly $\$ 47$ billion in 2010 to about $\$ 103$ billion in early 2021. In addition to wealth accumulation outpacing giving, there are also many questions about how billionaires spend their wealth. While many of these donors claim a desire to bring about transformative change, 
they often spend their resources to support very traditional causes, including already-wealthy universities or medical research. While $80 \%$ of wealthy donors in the USA state that fostering social change is a priority for them, only $20 \%$ of their actual spending supports social justice-related causes (Foster et al. 2016). Foundation funding focused on people of color in the USA has never exceeded $8.5 \%$ of total spending (Villanueva 2018). A new generation of donors, exemplified by Mackenzie Scott's unbureaucratic give-away of nearly US $\$ 6$ billion during the COVID-19 pandemic, may signal a major generational shift in priorities (Çam 2021).

An important recent initiative to enhance the philanthropic activities of billionaires is the Giving Pledge, a voluntary commitment to give away at least half of one's wealth before death. Created in 2010 by Bill and Melinda Gates, in collaboration with Warren Buffet, the Giving Pledge has 220 signatories today (as of March 2021). The pledge "aims over time to help shift the social norms of philanthropy toward giving more, giving sooner, and giving smarter" (The Giving Pledge 2019). While this type of "super-philanthropy" is increasing the power of a small number of individuals over public policy, our understanding of these actors remains limited (Rogers 2015) and is often shaped by a focus on a few, high-profile examples. A broader empirical basis drawn from billionaires joining the Giving Pledge can offer new insights into the role of philanthropic giving as a major activity of the wealthy. To expand our understanding of how billionaires communicate to the public their philanthropic aspirations, this article provides a descriptive analysis of the Giving Pledge population, its demographic composition, and the main themes discussed in letters submitted by signatories at the time of their pledge.

The Giving Pledge population is predominantly male, white, and based in the USA. The letters cover explanations for giving, examples of past or ongoing philanthropic activities, family and personal history, and references to the Giving Pledge founders as well as why couples and individuals have joined the Giving Pledge. The dominant causes mentioned in the letters are education and health. With regard to explanations for giving, a set of four dominant themes emphasize a desire to make a difference, a wish to give back, a sense of personal fulfillment resulting from giving, and references to being socialized into philanthropic giving early in life. Five minor explanations include a sense of stewardship, a desire to not burden offspring with a large inheritance, an acknowledgement of excess wealth, wanting to leave a legacy, and religious or spiritual inspiration. Overall, the vast majority of Giving Pledge letters paint a traditional picture of philanthropy with no significant transformative and critical perspectives questioning wealth accumulation in the first place. Pledgers display a sense of "hyperagency" (Schervish 2005) that communicates confidence in their ability to address major social problems typically solved through collective action organized by governments or social movements.
The article first provides an overview of the Giving Pledge and its history. The subsequent section reviews recent debates on billionaire philanthropy with a particular focus on how current debates have either defended or vilified billionaire philanthropic giving. The findings section covers two main areas: an analysis of demographic information about the pledgers and a discussion of Giving Pledge letter contents. With regard to letter contents, the analysis provides a sense of the overall frequency of mentioned philanthropic causes and explanations for giving. The closing sections summarize the key results and offer a broader assessment of the Giving Pledge and its effectiveness with regard to increasing philanthropic resources available for deserving causes.

\section{The Giving Pledge}

In the aftermath of the 2008/2009 global financial crisis, Warren Buffett and Bill and Melinda Gates organized a number of informal meetings among a small group of wealthy donors to explore the best ways of nudging fellow billionaires into increased philanthropic investments. These meetings generated a host of ideas about increasing giving, but also revealed that many billionaires preferred keeping their philanthropy private and were unlikely to join any collective effort with very stringent expectations (Loomis 2010). In the end, the founders settled on a pledge which invites fellow billionaires "to give at least half of their wealth to charity in their lifetime or at their death."

The Giving Pledge is voluntary and aims at increasing philanthropic giving among the wealthy while also bringing "together those committed to this kind of giving to exchange knowledge on how to do this in the best possible way" (The Giving Pledge 2020). An annual retreat has become a major gathering point providing the members with opportunities for shared learning, including how to invest in scientific research and other causes (Callahan 2017, 26). Some of the letters submitted as part of joining the Giving Pledge are directly addressed to the founders and reveal that Warren Buffett and Bill and Melinda Gates have actively recruited new members throughout the past decade.

A key inspiration for the Giving Pledge endeavor was Chuck Feeney and his Atlantic Philanthropies' "Giving While Living" campaign (Bertoni 2018). Feeney's example of giving away all his wealth inspired Bill Gates to establish the pledge and use personal appeals to fellow billionaires. "Chuck's long-standing commitment to Giving While Living has been a guidepost for Melinda and me" (Bill Gates, cited in: Soskis 2017, 46). Feeney himself joined the Giving Pledge in 2013, although he had serious reservations because it did not require actual spending of philanthropic resources while living (Soskis 2017, 47). The Giving Pledge does not require pledgers to provide evidence of philanthropic 
investments, and it can be met by transferring resources to a foundation or entity distributing resources over many decades.

\section{Understanding Billionaire Philanthropy}

There are three core areas of concern defining an expanding research agenda on billionaire philanthropy. The first one relates to how wealth is generated across economic systems and how new resources define and change the philanthropic landscape (inputs). The second issue emphasizes how the philanthropic system actually operates and in what ways foundations' internal and organizational practices are aligned with espoused goals (throughputs). Finally, the third major issue concerns the results of philanthropic activities and in what ways philanthropists shape the everyday lives of their fellow citizens (outputs).

First, the massive accumulation of wealth and its philanthropic outputs present a key public policy challenge today. "Billionaire wealth has risen by an annual average of 13 percent since 2010 - six times faster than the wages of ordinary workers" (Oxfam International 2018). The COVID-19 pandemic has further exacerbated this trend as billionaires became some of its main financial beneficiaries by adding billions of dollars to their portfolios (Tiku \& Greene 2021). This massive growth in wealth will have significant long-term ramifications, giving very few individuals even more influence to shape the nonprofit sector and public policies. This influence is further exacerbated as the wealthy have access to additional public funds allocated to them through generous tax deductions (Reich 2018). While billionaire philanthropy is gaining in relative importance, the percentage of US households giving to charitable causes dropped from $66 \%$ in 2000 to $55 \%$ in 2014 (Rooney 2018). These developments increase the risks of diminishing the important role of community-based giving practices, including Giving circles, as major contributions to democracy and addressing social issues equitably (Carboni \& Eikenberry 2021).

Second, philanthropy as a social practice can also be explored by focusing on its internal norms and organizational practices. After extensive debates on strategic philanthropy during the past decade (Kania et al. 2014), the pandemic and growing demands for decolonizing philanthropy have focused attention on how foundations and other philanthropic actors value specific types of knowledge in making their funding decisions (Sudarkasa 2021). It has also increased demands to democratize decision-making power in grant-making: not just to diversify the ranks of fundraisers and grantees, but to adopt fundamentally different philanthropic practices. "Up until now, diversity and inclusion tactics have been about getting different kinds of people in the door, and then asking them to assimilate to the dominant colonizer white culture" (Villanueva 2018, 65).
Some philanthropists have recently responded to these concerns by fundamentally changing how donations are distributed. For example, among the Giving Pledge members, Mackenzie Scott has received attention for giving away close to US $\$ 6$ billion during the COVID-19 pandemic in mid- to late 2020. She has done so without attaching cumbersome reporting requirements and has specifically targeted her donations to support organizations led by people of color and other non-traditional leaders (Dale 2020). As a philanthropic practice, this challenges deep-seated traditional practices emphasizing control over donor funds and recipients exercised by often white and male philanthropists.

Third, the outputs and outcomes of wealthy giving have received extensive and often controversial attention by their defenders and critics expressing often incompatible views. Much of the popular writing on wealthy philanthropy focuses on the perceived societal benefits and harms associated with the growing prominence of ultra-rich giving. Proponents of this type of giving have advanced a number of claims about its unique contributions. One argument is that foundations emerging from private wealth can pursue innovation and long-term social change much more consistently and persistently than governments or commercial markets (Reich 2016). While foundations can act largely independently from external pressures, governments may be subject to short-term voter demands, while businesses face profit motives possibly shortening their time horizons and willingness to invest in public goods. Another claim emphasizes the agility and innovativeness of "philanthrocapitalism," i.e., the well-intentioned pursuit of public goods using the principles of private enterprise (Bishop \& Green 2008). This argument is often repeated in popular discourse with regard to billionaire philanthropists and their alleged capacity to bring their proven business acumen to the not-for-profit world.

Critics of this kind of philanthropy point out that the growing concentration of wealth effectively undermines democracy by handing control of essential public services to the ultra-rich (Saunders-Hastings 2018). Decisions about public health or school systems are increasingly made in the offices of grantmakers, not at the ballot box (Barkan 2011; Goss 2016). Philanthropy may then also serve to undermine any efforts at reducing widening income inequality through taxing the rich (Dalzell 2013, 145). The wealthy could then be increasingly viewed as more capable of addressing societal problems, although widening wealth inequality is a major cause of government incapacity in the first place.

While critiques of this type of philanthropy are today common, there is little agreement on which particular harm is most relevant to address. Some argue that the main problem is that billionaire philanthropists are pushing both market-based solutions as well as business practices to be 
adopted in the not-for-profit and governmental realms (Giridharadas 2018). The main target of this type of critique is the new generation of philanthropists exerting their powerful influence and undermining the independence of the not-for-profit sector while also staying silent on rising income inequality. Giridharadas dissects the sphere he calls "MarketWorld," comprised of the individuals in Silicon Valley, the Aspen Institute, the Clinton Global Initiative, and similar venues. He makes the case that while these donors claim to promote programs and policies aimed at alleviating poverty and inequality, their frequent insistence on market solutions to social problems is inherently self-serving. Worse, the manner by which fortunes are created directly contributes to the exacerbation of social and economic inequalities (Eikenberry \& Mirabella 2018; McGoey 2016). Contrary to what one might expect, "three and a half decades' worth of wondrous, head-spinning change [have had] zero impact on the average pay of 117 million Americans" (Giridharadas 2018, 4).

Another set of critics emphasizes the rise of "dark money" shaping public policy by funding think-tanks and aligned institutions (Callahan 2017). The focus here is less on how philanthropy spreads technocracy and business principles, but how it captures the democratic sphere using its own set of think tanks and lobby groups. What matters then is what political cause is being supported. Depending on one's political outlook, the Koch brothers' philanthropy is then viewed very differently from the investments in higher education or gun control by Michael Bloomberg (Callahan 2018).

Callahan (2017) as well as Page, Seawright, and Lacombe (2018) argue that the real problem is not fashionable and highly visible tech billionaires, but the far more influential group of conservative donors who over the past 40 years have changed the national conversation in the USA through their gifts to conservative think-tanks. By promoting public policies designed to shift wealth from labor to capital as well as fiscal contraction of government budgets, these donors have succeeded for decades in shaping the discourse about economic and other policies issues. In contrast to the more visible Bill Gates or Michael Bloomberg, they shun publicity and engage in "stealth politics" (Page et al. 2018). This creates a threat to democracy not necessarily because private foundations take over public services and spread corporate business practices, but because major influences on public policy remain invisible.

\section{Methods and Data}

Letters of the pledge population were downloaded from the Giving Pledge website and then imported into NVivo 12, a computer-aided qualitative data software. The letters were read by both authors, and additional demographic information about the pledgers was collected from public sources, including Forbes and Glasspockets. Where available, we added personal data about the pledgers, including their age at time of pledge, their citizenship, their fortune size at time of pledge, number of children, industry, their Forbes self-made score, and their Forbes philanthropy score. As part of a content analysis of the causes identified in the letters, we coded all instances of specific philanthropic activities. As part of a thematic analysis of the philanthropic explanations for giving, we coded both inductively and deductively by drawing on existing literature about giving among the wealthy. Similar concepts were combined, while fundamentally different ones were differentiated based on existing categories. For example, references to giving back or being blessed were combined under a sense of gratitude toward the community and others. Mentions of experiencing joy or finding personal rewards in giving where categorized as experiencing personal gratification.

\section{The Demographics of the Giving Pledge}

As of March 2021, there are 220 signatories from 25 countries. After 57 pledgers joined during the first year, the membership grew on average by almost 16 pledgers annually between 2011 and 2020. In 2013, the Giving Pledge was opened to international signatories. Figure 1 provides an overview of annual new membership and growth over the past decade. Today, $168(76 \%)$ of the 220 pledgers are US citizens. The only other countries with more than two citizens as members are the UK (13), India (7), China (5), and Canada (5). The remaining pledgers are distributed across 20 countries, including three from the Persian Gulf region, and three from the African continent. Among the US billionaire population listed in the 2020 Forbes 400 , four of the top ten billionaires (Buffett, Ellison, Gates, and Zuckerberg) and 74 of the top 400 (18.5\%) have joined the Giving Pledge (Wang 2020). In 2020, the Giving Pledge members represented more than $10 \%$ of an estimated population of 2095 billionaires in the world. In early 2021, this estimated number of billionaires increased to 2755 (Forbes 2021), which substantially increases the potential membership for the Giving Pledge.

The average age of pledgers at the time of joining is 63.3 years (median: 64 years). Twenty-six pledgers are now deceased. At the time of their pledge, ten were members of the Greatest Generation (born before 1928), 79 belonged to the Silent Generation (born between 1928 and 1945), 84 were Boomers (1946-1964), 38 were Generation X (1965-1976), and nine were Generation Y/ 
Fig. 1 Annual growth of giving pledge membership, 2010-2020
Giving Pledge membership: 2010-2020

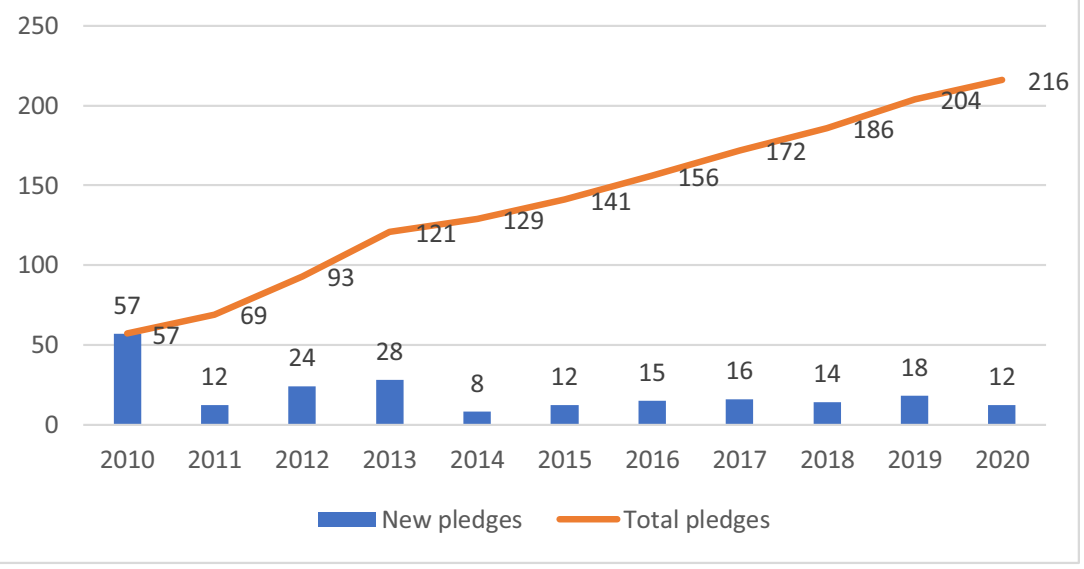

Millennials (1977-1995). ${ }^{1}$ Dustin Moskovitz, the youngest pledger to join at age 26 in 2010, is a co-founder of Facebook and has a fortune of about US $\$ 20$ billion today.

The vast majority of pledgers are categorized as self-made billionaires. Only $36(16 \%)$ have inherited their wealth, while $184(84 \%)$ are categorized as self-made. The average Forbes self-made score for 92 of the pledgers scored by Forbes is 7.8 on a scale from 1 to 10 (Kroll 2018). Membership in the Giving Pledge includes 131 couples, 79 single males, and 10 single women. The total number of men participating is 210 , compared to 141 women. Among the ten women who joined as individuals, six are self-made billionaires (Blakely, Faulkner, Gloag, Hill, Mazumdar-Shaw, You), three have inherited their wealth after the death of their husbands (Dolby, Schusterman, White), and two presumably received their wealth in divorce settlements (Arnall, Scott). With very few exceptions, the men are the wealth generators among couples, showing the gendered nature of global wealth distribution. There are currently no same-sex couples listed.

The members of the Giving Pledge control well over US \$1 trillion in assets. For 126 pledgers with available data, the average fortune at the time of their pledge was US \$5 billion. The median was US $\$ 2.4$ billion, indicating a significant wealth inequality even among this population. Based on Forbes and other data, the pledge population can be categorized into three general sources of wealth: technology (54 pledgers), finance (63 pledgers), and a "brick and mortar" category (103 pledgers) comprising more traditional industries including the energy, retail, real estate, health care, and other sectors. "Brick and mortar" pledgers are on average the

\footnotetext{
${ }^{1}$ There are no generally agreed-upon time demarcations for Generations $\mathrm{X}$ and Y. The term "Millennial" is frequently used in the popular press to refer to those born from the 1980s until the early 2000s "Here Is When Each Generation Begins and Ends, According to Facts," The Atlantic, updated March 25, 2014, https://www.theatlantic.com/national/archive/2014/03/hereis-when-each-generation-begins-and-ends-according-to-facts/359589/.
}

oldest population (68.3 years), followed by finance (63.9 years), and tech (53.3 years). Wealth distribution at the time of pledge ${ }^{2}$ also varies significantly across the three sectors. Tech billionaires have an average of US $\$ 6.91$ billion (median: US $\$ 3.2$ billion) in wealth. Finance billionaires average US $\$ 5.15$ billion (median: $\$ 2$ billion) in wealth. "Brick and mortar" signatories controlled an average of US $\$ 3.73$ billion at the time of their pledge (median: US $\$ 2$ billion). Pledgers in the technology category are both significantly younger and wealthier than their counterparts. In addition, some pledgers have increased their wealth after they joined the Giving Pledge. For example, in 2010 the wealth of Bill and Melinda Gates was estimated to be US $\$ 54$ billion, while today their estimated net worth is US $\$ 130.8$ billion (as of March 2021).

The Giving Pledge considers anyone with a current net worth of US \$1 billion or more as eligible, but is also open to those who would be billionaires "if not for their giving" (The Giving Pledge 2020). For example, Charles Feeney joined the Giving Pledge in 2013 after he had already given away most of his wealth, while Ron Conway emphasized in his letter that he is a "proud never-billionaire" who has consistently made large donations during his lifetime. In fact, a significant number of pledgers have engaged in philanthropy for decades and their pledge simply confirms what they have already committed to.

Seventy-four of the pledgers have received a Forbes philanthropy score ranging between 1 and 5 . The average score for this group is 3.6. Among the current list of Forbes 400 billionaires, only seven pledgers received the top score (Arnold, Broad, Buffett, Kaiser, Robertson, Schusterman, Turner), which indicates that they have given away at least $20 \%$ of their wealth (Wang 2020). An investigation into the

\footnotetext{
${ }^{2}$ Data of wealth assets at the time of pledge were available for 56 out 103 "brick and mortar" signatories, 36 of 63 finance signatories, and 34 of 54 tech signatories.
} 
giving patterns of ten deceased pledgers revealed that they had likely failed to give away half of their fortune at time of their death (cited in: Soskis 2017, 47).

\section{Who Signed the Giving Pledge?: Letters and Pictures of Signatories}

By March 2021, a total of 196 pledgers submitted letters ranging in length from 41 to 1447 words. The total word count of all letters combined is 87,338 . The average length of the letters is 445.6 words (median: 402). Five pledgers have submitted letters, but have only made a quote publicly available (Masiyiwa, McCaw, Parsons, and Tahir). Twenty-four pledgers have not (yet) submitted a letter, including Elon Musk. The letters of pledgers are paired with pictures of the individuals and couples. Among the 220 pledgers, 188 submitted pictures and 32 have not (22 couples and 10 male pledgers). Among couples, there are twelve instances where only the male pledger is pictured, but both are listed as pledgers. There are no instances of only the female represented in a picture for a couple pledging.

The invitation to join the Giving Pledge and provide a letter inspires reflections on the pledgers' own life journeys, philosophical guideposts for giving, family relations, and other topics. The letters' contents can be divided into six broad categories: comments on joining the Giving Pledge and its creators, statements about what motivates giving, descriptions of philanthropic activities and causes supported in the past or present, family and personal history, strategies of giving explained, and miscellaneous other statements.

\section{Philanthropic Causes}

The letters of 145 billionaires or $74 \%$ of all letters reveal some of their past or current philanthropic spending. Table 1 summarizes the major causes and their subcategories. The causes identified in the letters were categorized based on the National Taxonomy of Exempt Entities (NTEE) Core Codes (Jones 2019).

The letters do not provide a comprehensive account of each pledgers' past giving behavior. Instead, they offer snapshots of the most important philanthropic activities likely chosen by the authors as highlights and proud accomplishments. Notable is the overall dominance of health and education as the top causes. In addition, those categories are also prominent in the third "international" category. Compared to the general public (King 2017), religious causes play a very minor role, at least in terms of frequency of explicit mention in the Giving Pledge letters.

A majority of pledgers emphasizes individual opportunity and entrepreneurship as central to what they associate with successful philanthropy. Pledgers often refer to their own success as a way of explaining why they view individual opportunity - primarily advanced by educational opportunity and other means - as central to addressing social and economic ills. George Kaiser mentions that "America's social contract is equal opportunity," while Glenn Dubin states "I started my career with nothing but opportunity." Bill and Melinda Gates see much progress in the educational system of the USA, but want to ensure "that every student gets the same opportunity to succeed in college and in life." The underlying theory of change primarily emphasizes creating a level playing field within the existing educational or healthcare system, but there
Table 1 Causes identified in the Giving Pledge letters*

\begin{tabular}{|c|c|c|c|}
\hline Cause & Freq. & Percent & Subcategories \\
\hline Education & 90 & 45.91 & K-12 (47), higher education (31), general education (24) \\
\hline Health & 64 & 32.65 & Medical research (37) Health services (35); general health (4) \\
\hline International & 46 & 23.46 & $\begin{array}{l}\text { Development (38), peace and conflict resolution (9), humanitarian } \\
\text { relief (6) }\end{array}$ \\
\hline $\begin{array}{l}\text { Environment, } \\
\text { animal welfare }\end{array}$ & 35 & 17.85 & $\begin{array}{l}\text { Conservation (27), climate (12), animal welfare/general environment } \\
\text { ( } 2 \text { each) }\end{array}$ \\
\hline $\begin{array}{l}\text { Public or social } \\
\text { benefit }\end{array}$ & 30 & 15.30 & $\begin{array}{l}\text { Non-medical research (16), community development (12), human } \\
\text { and civil rights (4) }\end{array}$ \\
\hline Human services & 26 & 13.26 & $\begin{array}{l}\text { Women (9), children (7), military (4) homeless/food security/- } \\
\text { economic opportunity ( } 3 \text { each) }\end{array}$ \\
\hline $\begin{array}{l}\text { Arts, culture, } \\
\text { humanities }\end{array}$ & 25 & 12.75 & Not applicable \\
\hline Public policy & 21 & 10.71 & $\begin{array}{l}\text { General public policy (9), governance (6), healthcare reform (3), } \\
\text { crime/drug/media policy ( } 2 \text { each) }\end{array}$ \\
\hline Religion & 10 & 5.10 & Not applicable \\
\hline
\end{tabular}

* Subcategory totals may exceed the frequency counts because some pledgers mentioned more than one subcategory. Causes were mentioned in 145 of 196 letters; percentages are calculated based on $n=196$ 
are only rarely mentions of the many structural impediments to individual success, including shortages of housing or systemic discrimination.

Topics such as racial justice, diversity, or community development are very rarely or never mentioned in the letters. This aligns with prior research on wealthy donors, which has shown significant gaps between their aspirations to support social change and the causes they actually fund. "In fact, the great majority of wealthy Americans' philanthropic giving goes to large institutions - such as universities, hospitals, and cultural institutions - that are vital to a healthy society, but may not make progress against donors' stated priorities" (Ditkoff et al. 2018, 11).

Important exceptions to the traditional understanding of philanthropic causes across the letters include the recent letters by Ron and Gayle Conway mentioning racial injustice and the statement by Reid Hoffman and Michelle Yee emphasizing a community focus:

It is important for us to note, however, that philanthropy also seeks more than simply outcomes. It is also a form of community engagement. This engagement is a partnership between multiple stakeholders, the most important being the members of the community directly affected by the engagement.

\section{Explanations for Giving}

Another major subject of the pledge letters focuses on how the signatories explain their giving. Since the letters are publicly available and written as part of joining the pledge, they may not reveal the true motivations driving philanthropic activities, but they do reveal how the pledgers would like others and the public to perceive of their generosity. Prior research on the Giving Pledge letters has identified already some of these explanations (Sadeh et al. 2017), while earlier studies on the philanthropy of the wealthy has also generated insights into how these donors make sense of their giving (Breeze \& Lloyd 2013; Horvath \& Powell 2020; Schervish 2007; Worth et al. 2019). A study focused on pledgers from the tech sector found that "they were more likely than the other Pledgers to have an expansive and positive vision of philanthropic endeavor" (Brockmann et al. 2021, 21).

The explanations used by signatories to explain their generosity can be divided into nine distinct categories: wanting to make a difference (mentioned in 80 or $40.82 \%$ of all letters), gratitude and a desire to give back $(78,39.80 \%)$, psychological benefits experienced $(56,28.57 \%)$, family socialization $(50,25.51 \%)$, a sense of stewardship of resources $(26$, $13.27 \%)$, the idea of having excess wealth $(21,10.71 \%)$, the desire to not burden offspring with a large inheritance (20,
$10.20 \%)$, wanting to leave a legacy $(15,7.65 \%)$, and a reference to religious beliefs $(15,7.65 \%)$.

Making a Difference The most frequently mentioned reason to give is a desire and belief in making a difference. Prior research on wealth donors has labeled this as "hyperagency" since many of these donors feel "capable of establishing the institutional framework within which they and others live" (Schervish 2005, 60). "Walt Disney once said, 'It's kind of fun to do the impossible, and like the three of you, I am in the fortunate position to help tackle some of life's most challenging "impossibilities"' (Hill).

Many of the pledgers see it as their duty to improve the human condition through their talents and resources. "My ambition now is to do the most good possible with my wealth" (Delo). The term "making the world a better place" is used in a number of letters (e.g., Ragon, Rales, Ross, Secunda, Wood), while the capacity of philanthropists is favorably compared to slow and ineffective governments (e.g., Craft, Perelman, Stanley, Stevens). Pledgers not only consider their philanthropy as capable of altering the conditions under which others live, but also typically claim that their efforts will be effective and successful. "I have always believed that those who have the abilities and opportunities to accumulate wealth should utilize their skills, in addition to their wealth, to solve the world's problems" (Arnall).

Gratitude to the Community Gratitude and a desire to give back to society constitute the second most frequent explanation for philanthropic activity. Pledgers may refer to their communities and support received as a core reason for giving. "America's free enterprise system has enabled us to be successful beyond our imaginations, which we believe is accompanied by the obligation to give back to improve the lives of others" (Klarman). Immigrant experiences may also serve as a background to wanting to return something back to their host societies. "There has existed in the minds of refugees, who have been embraced by this great country, a level of gratitude for the opportunities [...] that is somewhat analogous to a debt that we feel needs to be repaid" (Taube).

A desire to give back may be prompted by different underlying perceptions. In some letters, it reflects a noblesse oblige, or a sense that being set apart from everyone else generates certain obligations. "I strongly believe that those of us, who are privileged to have wealth, should contribute significantly to try and create a better world for the millions who are far less privileged" (Premji). Others derive a sense of gratitude from having become rich as a result of sheer luck and good fortune. "I recognized early on that my fortune was not due to superior personal character or initiative so much as it was dumb luck" (George Kaiser). References to one's personal experience, including upbringing (see also below), are often combined with a sense of gratitude. "I have been blessed with a great deal of 
good fortune in my life. For me, the Giving Pledge is an expression of my desire to give back, both to my community and to the wider world" (Prince Alwaleed Bin Talal Bin Abdulaziz AlSaud).

Personal Gratification Experienced The personal rewards of philanthropy spelled out by 56 pledgers include the emotional and psychological benefits ("warm glow") experienced by helping others. In the majority of references, pledgers identified philanthropy as a satisfying activity sometimes more pleasurable than earning wealth. "My message to those who have not yet found philanthropy is that they may well find that it becomes a drug that gives far more pleasure than the creation of wealth" (Caudwell). There are also references to the "fun" (Broad) experienced in giving as well as having company staff involved in giving decisions and making "surprise visits to organizations with checks in hand and witness the tears first hand" (Blakely). Similar to existing research finding close links between altruistic and more selfish impulses (Herzog \& Price 2016), many pledgers link their own wellbeing to an expressed empathy and desire to enhance the wellbeing of others. "I get tremendous pleasure from helping others. It's what makes my life worth living" (Ackman).

Family Socialization Family upbringing and parents or other relatives are mentioned by 50 pledgers elaborating on how a sense of philanthropic duty emerged very early in life. For example, "...my mother gave my brother and I a dime. She told the both of us to hold it together and place it inside the bucket near a man who was ringing a bell" (DeJoria). In some cases, both a sense for business and philanthropy are closely linked and emerge together as part of being raised and educated. "My parents taught me about business and entrepreneurship and also about the duty of giving and caring for the poor and marginalized" (Motsepe). As a mechanism of socialization, family upbringing is cited as instilling a sense of empathy and responsibility to give back and be generous without ulterior motives. "From as far back as I can remember, my parents taught me the importance of giving back, whether we had a little or a lot" (Pattison).

Stewardship A smaller number of letters explicitly raise a broader moral context relevant to the philanthropy of billionaires. Twenty-six signatories refer to themselves in various ways as stewards, not owners of their wealth, or they explicitly question the inequality of wealth distribution. "Claire and I never believed that the wealth we accumulated was truly ours..." (Tow). These references may be linked to the recruiting efforts by Warren Buffett, who has told prospective pledgers that their wealth is not theirs to keep and should be distributed while being alive. Closely related to stewardship are references in a few letters which frame the obligation to give as a response to deep economic inequalities and injustices. "It's our civic obligation. The income gap between top and bottom earners is too great...." (Butt). Erica and Jeff Lawson cite Bryan Stevenson, the founder of the Equal Justice Initiative: "The opposite of poverty is not wealth; the opposite of poverty is justice."

Excess Wealth Twenty-one of the letters identified philanthropy as the best use of excess wealth. This includes a sense that personal consumption beyond a certain level does not contribute to happiness. "Service to others seems the only intelligent choice for the use of wealth. The other choices especially personal consumption seem either useless or harmful" (Bhargava). Others state bluntly that having wealth is unhelpful after one's death. "I have never seen a hearse pulling a UHaul trailer. You can't take it with you" (Ueltschi). Giving here is typically either a residual category of disposing of excess resources or it emerges as an important option in the process of realizing one's mortality. Letters also reveal that this class of donors does not have to make any sacrifices when being philanthropically active. "We have so much more than we could ever possibly use or need, that giving is relatively painless" (Lefkovsky).

Avoid Harm to Children A focus on one's own family and the possible harm of inherited wealth emerges as an explicit reason for giving in about $10 \%$ of the letters. "We all know second and third generation wealth where the recipients were actually born on third base but think and act like they hit a triple" (Jordan). Pledgers report having seen the problems experienced by wealthy offspring or express an expectation that their children should replicate the self-made careers of their parents. "Giving wealth to young and future unborn children, in our opinion, reduces or eliminates the characterbuilding challenges ahead of them in life that they would otherwise face" (Lenfest). Especially those with self-made wealth may consider leaving a fortune as harming the character of children, while considering their own experience of going from less well-off to wealthy as formative and ultimately beneficial. "Traditionally, societies focused on ancestorworship, but as Americans, we have mostly descended from penniless, indentured, or fugitive antecedents, so it really makes no sense to us to try to derive importance from our birth, and thank goodness for that" (Steyer and Taylor).

Leaving a Legacy References to "legacy" appear in fifteen letters and are typically closely linked to the desire to make a difference, even after one's passing. "Sharing our good fortune with others allows our legacy and purpose to become lasting and meaningful" (Metropoulos). One of the principal promoters of the Giving Pledge, Michael Bloomberg, uses his letter to list key reasons why others should join, including the legacy created. "Giving also allows you to leave a legacy that many others will remember. Rockefeller, Carnegie, Frick, Vanderbilt, Stanford, Duke - we remember them more for 
the long-term effects of their philanthropy than for the companies they founded, or for their descendants" (Bloomberg).

Religion Religion is a major motive for giving in the general population, but is rarely mentioned in the pledge letters. Only fifteen letters make explicit references to religion as a contributing factor. A majority of religious references reflect the influence of Jewish and Christian traditions. "In addition to caring for our own community, Jewish tradition teaches that we have a solemn duty to treat all people with respect and care. In the words of Maimonides, 'One ought to treat everyone with derekh eretz (civility and humanity) and hesed (mercy and kindness)"“ (Schusterman). This sense of duty may refer to underlying norms expressed in religious teachings or a desire to give back to the religious community in which one was raised. "In addition, we were both raised in the Church, and a key theme of the Bible is the importance, the necessity, of giving" (Jones).

In sum, frequency counts of giving reasons discussed in Giving Pledge letters provide some basic insights into how billionaires project their generosity to their peers and the public. This analysis can be deepened by exploring patterns of cooccurring explanations across letters and establishing broader rationales for giving emerging among billionaires (Schmitz et al. 2021). Considering the short letter format, the absence of a cause or explanation may simply be due to space limitations. Such concerns about missing data can only be fully addressed by triangulating the data from the Giving Pledge letters with additional sources and information on giving activities.

Separate from the distinct explanations for giving, pledgers also elaborate why they joined the Giving Pledge. Thirteen letters explicitly refer to the recruitment efforts by Bill Gates and Warren Buffett, or they mention being inspired by other prominent peers (e.g., Lawson, Mazumdar-Shaw, Varkey). Much more frequent are references to wanting to learn from others about philanthropic activities (41 letters) as well as wanting to inspire others to also join the Giving Pledge (53). Especially those with limited experience in philanthropy express a hope to learn from the collective expertise of other pledgers. "We are looking forward to the mentorship and community that comes with committing to The Giving Pledge" (Blecharczyk). Some pledgers also make clear that they had to be coaxed into joining the Giving Pledge and had long-standing concerns about the publicity of membership. "As a private person, I prefer to minimise publicity of my philanthropic activities but at the same time realise that setting a positive example is the best way to encourage others to give back" (Ainsworth).

\section{Discussion}

After a decade of existence, the Giving Pledge has attracted substantial attention and regular new membership. As a voluntary initiative with modest goals for its signatories, it has attracted a population of 220 Giving Pledge billionaires (as of March 2021) dominated by white males and US citizens. About half of the billionaires have made their wealth in "brick and mortar" industries, while the other half is almost equally split between finance and technology sectors. Pledgers from the tech sector are significantly younger and wealthier.

The causes identified in the letters are traditional in the sense of focusing primarily on education and health as key factors understood to foster individual opportunity. Issues of social justice, diversity, or inclusion are not significant causes and rarely mentioned in the letters. The dominance of health and education also indicate a status quo orientation that largely ignores the structural inequities underlying widening wealth gaps. In this worldview, the goal of philanthropy is to support individual opportunity, not to attempt a fundamental transformation of societies through active redistribution of wealth from the top down. The Giving Pledge letters exhibit significant parallels to Andrew Carnegie's Gospel of Wealth published in 1889 (Carnegie 1889/2017). Carnegie had also called on the wealthy to give during their lifetimes and identified education and health as the top recommended philanthropic investments.

The explanations for giving reveal patterns and accounts very similar to what earlier studies of wealthy donors have found. All of the major explanations mentioned in at least $25 \%$ of the letters have been identified and described before and reflect a focus on the desire to make a difference, give back to the community, personal benefits, and family upbringing. Five more minor explanations for giving include a sense of stewardship, references to excess wealth, a concern about wealth harming offspring, a desire to leave a legacy, and religious references. While counting specific instances of explanations expressed in the letters, this approach cannot create a complete account for each pledger or reveal the true motivations for philanthropy. Notably absent from the explanations are any references to tax benefits or expectations for reputational benefits possibly playing a role. The explanations recorded remain within a realm of what signatories may consider a socially desirable account of their generosity.

\section{Conclusions}

The Giving Pledge is today one of the most prominent efforts to increase philanthropic giving among the wealthy. As billionaires across the world face growing public scrutiny (Pearl 2020), the Giving Pledge has promised for a decade to increase philanthropic resources available for deserving causes. While the Giving Pledge is consistently attracting new members, it remains unclear if it is accomplishing some of its basic goals. Many of the early members had been major donors prior to joining, and their membership likely did not change their giving trajectory. Others may have joined with good intentions to give more, but the evidence from a small number of investigations suggests that the voluntary 
nature of the Giving Pledge may not sufficiently incentivize accelerated giving. Some of the prominent members of the Giving Pledge, including John and Laura Arnold, have recently joined the Global Citizen's "Give While You Live" campaign, which calls on donors to give a minimum of 5\% of their wealth annually. They have also co-founded the Initiative to Accelerate Charitable Giving (Initiative to Accelerate Charitable Giving 2021), which aims at creating improved incentives for more actual giving to the charitable sector. Compared to these more recent initiatives, the Giving Pledge is much less ambitious and cannot easily demonstrate its positive impact.

A much more immediate result of the Giving Pledge is the reputational benefits gained by its founders and members. The website and letters are not just designed to prod other billionaires to give, but act as a form of communication to the general public about the sincerity of motives and dedication to worthy causes among billionaires. The letters emphasize the generosity of the donors, provide many examples of good intentions, and promise to solve major societal challenges. The vast majority of letters do not question the structural conditions which drive widening economic inequality, including tax policies or underlying gender and racial divisions.

Future research on the Giving Pledge and its population could expand the data sources used. For example, claims made in the letters could be compared with data on actual giving behavior. It may also be worthwhile to collect other public statements of the pledgers to provide a more complete philanthropic picture that not only relies on the letters' contents. In addition, different philanthropic practices emerging across signatories are a promising avenue for additional research. For example, many wealthy donors have moved away from the traditional foundation incorporated under nonprofit law, and instead created limited-liability companies (LLCs). This includes the Chan Zuckerberg Initiative, the Emerson Collective, the Omidyar Network, and Arnold Ventures. While LLCs have greater flexibility with regard to distribution funds and are subject to fewer reporting requirements, they do not enjoy the tax benefits of a philanthropic foundation. More recently, Mackenzie Scott's effort to distribute donations quickly and without any major bureaucratic infrastructure has added further innovation to philanthropic practices among the wealthy. All of these innovations could make it increasingly difficult for journalists and scholars to track and study billionaire philanthropy. The Giving Pledge and its letters only tell a story of good intentions, but offer only limited transparency about real motives and actions.

\section{Further Reading}

Barkan, J. (2011). Got Dough? How Billionaires Rule Our Schools. Dissent, 58 (1), 49-57.
Bertoni, S. (2018). Looking for New Year Inspiration? Meet Chuck Feeney-the James Bond of Philanthropy. Forbes. Retrieved from https://www.forbes.com/sites/stevenbertoni/2018/01/01/lookingfor-new-year-inspiration-meet-chuck-feeney-the-james-bond-ofphilanthropy/

Bishop, M., \& Green, M. (2008). Philanthrocapitalism: How the Rich Can Save the World. London: Bloomsbury Press.

Breeze, B., \& Lloyd, T. (2013). Richer Lives: Why Rich People Give. London: Directory of Social Change.

Brockmann, H., Drews, W., \& Torpey, J. (2021). A Class for Itself? On the Worldviews of the New Tech Elite. PLOS ONE, 16 (1), e0244071.

Callahan, D. (2017). The Givers: Wealth, Power, and Philanthropy in a New Gilded Age. New York, NY: Alfred A. Knopf.

Callahan, D. (2018). Is Elite Change Really a "Charade?" What's Missing from a New Book That Bashes the Overclass. Retrieved from https://www.insidephilanthropy.com/home/2018/9/12/is-elitechange-really-a-charade-whats-missing-from-a-new-book-thatbashes-the-overclass

Çam, D. (2021). How Mackenzie Scott Gave Away Nearly \$6 Billion Last Year-and Ended up Richer. Forbes. Retrieved from https:// www.forbes.com/sites/denizcam/2021/04/06/how-mackenzie-scottgave-away-nearly-6-billion-last-year-and-ended-up-richer/

Carboni, J. L., \& Eikenberry, A. M. (2021). Do Giving Circles Democratize Philanthropy? Donor Identity and Giving to Historically Marginalized Groups. Voluntas, 32 (2), 247-256.

Carnegie, A. (1889/2017). The Gospel of Wealth. New York: Carnegie Corporation of New York.

Dale, E. J. (2020). 5 Ways Mackenzie Scott's \$5.8 Billion Commitment to Social and Economic Justice Is a Model for Other Donors. Retrieved from https://theconversation.com/5-ways-mackenziescotts-5-8-billion-commitment-to-social-and-economic-justice-is-amodel-for-other-donors- 152206

Dalzell, R. F. (2013). The Good Rich and What They Cost Us: The Curious History of Wealth, Inequality, and American Democracy. New Haven: Yale University Press.

Ditkoff, S. W., Powell, A., Gardner, K., \& Tierney, T. (2018). Four Pathways to Greater Giving. Boston: Bridgespan Group.

Eikenberry, A. M., \& Mirabella, R. M. (2018). Extreme Philanthropy: Philanthrocapitalism, Effective Altruism, and the Discourse of Neoliberalism. PS: Political Science \& Politics, 51 (1), 43-47.

Ferris, J. M. (2016). Is This a New Golden Age of Philanthropy? An Assessment of the Changing Landscape. Voluntary Sector Review, 7 (3), 315-324.

Forbes. (2021). World's Billionaires List. Forbes. Retrieved from https:// www.forbes.com/billionaires/

Forbes Wealth Team. (2021). America's Top Givers: The 25 Most Philanthropic Billionaires. Forbes. Retrieved from https://www. forbes.com/sites/forbeswealthteam/2021/01/19/americas-topgivers-the-25-most-philanthropic-billionaires/

Foster, W., Perreault, G., Powell, A., \& Addy, C. (2016). Making Big Bets for Social Change. Stanford Social Innovation Review (winter), 26-35.

Giridharadas, A. (2018). Winners Take All. The Elite Charade of Changing the World. New York: Penguin Random House.

Goss, K. A. (2016). Policy Plutocrats: How America's Wealthy Seek to Influence Governance. PS: Political Science \& Politics, 49 (3), 442 448.

Herzog, P. S., \& Price, H. E. (2016). American Generosity: Who Gives and Why. New York: Oxford University Press.

Horvath, A., \& Powell, W. W. (2016). Contributory or Disruptive: Do New Forms of Philanthropy Erode Democracy? In R. Reich, C. Cordelli, \& L. Bernholz (Eds.), Philanthropy in Democratic Societies. History, Institutions, Values (pp. 87-122). Chicago: The University of Chicago Press. 
Horvath, A., \& Powell, W. W. (2020). Seeing Like a Philanthropist. From the Business of Benevolence to the Benevolence of Business. In W. W. Powell \& P. Bromley (Eds.), The Nonprofit Sector. A Research Handbook (3rd ed., pp. 81-122). Palo Alto: Stanford University Press.

Initiative to Accelerate Charitable Giving. (2021). About Us. Retrieved from https://acceleratecharitablegiving.org/about/

Jones, D. (2019). National Taxonomy of Exempt Entities (NTEE) Codes. Urban Institute. Retrieved from https://nccs.urban.org/project/ national-taxonomy-exempt-entities-ntee-codes

Kania, J., Kramer, M., \& Russell, P. (2014). Strategic Philanthropy for a Complex World. Stanford Social Innovation Review (Summer).

King, D. (2017). How Religion Motivates People to Give and Serve. Retrieved from https://theconversation.com/how-religionmotivates-people-to-give-and-serve- 81662

Kroll, L. (2018). The Forbes 400 Self-Made Score: From Silver Spooners to Bootstrappers. Forbes. Retrieved from https://www.forbes.com/ sites/luisakroll/2018/10/03/the-forbes-400-self-made-score-fromsilver-spooners-to-bootstrappers/\#660244c16cd9

Kulish, N. (2021). Why Buy a Yacht When You Can Buy a Newspaper? New York Times. Retrieved from https://www.nytimes.com/2021/ 04/10/business/newspaper-billionaire-owners.html

Loomis, C. J. (2010). The $\$ 600$ Billion Challenge. Fortune. Retrieved from https://fortune.com/2010/06/16/the-600-billion-challenge/

McGoey, L. (2016). No Such Thing as a Free Gift: The Gates Foundation and the Price of Philanthropy. London: Verso.

Oxfam International. (2018). Reward Work, Not Wealth. Oxford: Oxfam GB.

Page, B. I., Seawright, J., \& Lacombe, M. J. (2018). Billionaires and Stealth Politics. Chicago: University of Chicago Press.

Pearl, M. (2020). Billionaires Are Failing Us When We Need Them Most. Retrieved from https://www.cnn.com/2020/04/06/ perspectives/billionaires-coronavirus/index.html

Reich, R. (2016). On the Role of Foundations in Democracies. In R. Reich, C. Cordelli, \& L. Bernholz (Eds.), Philanthropy in Democratic Societies. History, Institutions, Values (pp. 64-81). Chicago: The University of Chicago Press.

Reich, R. (2018). Just Giving. Why Philanthropy Is Failing Democracy and How It Can Do Better. Princeton: Princeton University Press.

Rogers, R. (2015). Why the Social Sciences Should Take Philanthropy Seriously. Society, 52 (6), 533-540.

Rooney, P. (2018). The Growth in Total Household Giving Is Camouflaging a Decline in Giving by Small and Medium Donors: What Can We Do About It? Nonprofit Quarterly. Retrieved from https://nonprofitquarterly.org/total-household-growth-declinesmall-medium-donors/

Sadeh, J., Tonin, M., \& Vlassopoulos, M. (2017). Why Give Away Your Wealth? An Analysis of the Billionaires' View. In J. Costa-Font \& M. Macis (Eds.), Social Economics (pp. 61-78). Cambridge: MIT Press.

Saunders-Hastings, E. (2018). Plutocratic Philanthropy. The Journal of Politics, 80 (1), 149-161.

Schervish, P. G. (2005). Major Donors, Major Motives: The People and Purpose Behind Major Gifts. New Directions for Philanthropic Fundraising, 47, 59-87.
Schervish, P. G. (2007). Why the Wealthy Give. In A. Sargeant \& W. Wymer (Eds.), The Routledge Companion to Nonprofit Marketing (pp. 165-180). London: Routledge.

Schmitz, H. P., Mitchell, G. E., \& McCollim, E. M. (2021). How Billionaires Explain Their Philanthropy: A Mixed-Method Analysis of the Giving Pledge Letters. Voluntas, 32, 512-523.

Skocpol, T. (2016). Why Political Scientists Should Study Organized Philanthropy. PS: Political Science \& Politics, 49 (3), 433-436.

Soskis, B. (2017). The History of the Giving While Living Ethic. New York: Atlantic Philanthropies.

Sudarkasa, J. (2021). Telling My Truth as a Black Woman Made Me a Better Grant Maker. The Chronicle pf Philanthropy. Retrieved from https://www.philanthropy.com/article/telling-my-truth-as-a-blackwoman-made-me-a-better-grant-maker

The Giving Pledge. (2019). History of the Pledge. Retrieved from https:// givingpledge.org/About.aspx

The Giving Pledge. (2020). About the Giving Pledge. Retrieved from https:/givingpledge.org/About.aspx

Tiku, N., \& Greene, J. (2021). The Billionaire Boom. Washington Post. Retrieved from https:/www.washingtonpost.com/technology/2021/ 03/12/musk-bezos-zuckerberg-gates-pandemic-profits/

Villanueva, E. (2018). Decolonizing Wealth: Indigenous Wisdom to Heal Divides and Restore Balance. Oakland: Berrett-Koehler.

Wang, J. (2020). The New Forbes Philanthropy Score: How We Ranked Each Forbes 400 Billionaire Based on Their Giving. Retrieved from https://www.forbes.com/sites/jenniferwang/2020/09/08/the-newforbes-philanthropy-score-how-we-ranked-each-forbes-400billionaire-based-on-their-giving/?sh=51e652a09eba

Worth, M. J., Pandey, S., Pandey, S. K., \& Qadummi, S. (2019). Understanding Motivations of Mega-Gift Donors to Higher Education: A Qualitative Study. Public Administration Review, 80 (2), 281-293.

Publisher's Note Springer Nature remains neutral with regard to jurisdictional claims in published maps and institutional affiliations.

Hans Peter Schmitz is professor of leadership studies at the University of San Diego. He is the co-founder of the Transnational NGO Initiative at the Maxwell School of Citizenship and Public Affairs/Syracuse University. Most recently, he coauthored the book Between Power and Irrelevance. The Future of Transnational NGOs (Oxford University Press, 2020).

Elena M. McCollim , $\mathrm{PhD}$, is an adjunct associate professor at the University of Maryland Global Campus. Her research interests are in income inequality and nonprofit management. A practicing nonprofit professional, she also works as a grants manager at Survivors of Torture, International, a torture treatment center serving refugees and asylum seekers in San Diego, California. She previously worked in policy advocacy and in various international development nongovernmental organizations in Latin America and Washington, D.C. 